\title{
O statusie badań semiotycznych w dobie kultury cyfrowej
}

\begin{abstract}
Szczęsna Ewa, O statusie badań semiotycznych w dobie kultury cyfrowej [The status of semiotics research in the era of digital culture]. „Przestrzenie Teorii” 28. Poznań 2017, Adam Mickiewicz University Press, pp. 139-156. ISSN 1644-6763. DOI 10.14746/pt.2017.28.6.
\end{abstract}

This article proves the need to develop semiotics research focused on digital text, whose basic unit is the digital sign and which differs from other signs in its nature and structure. The changes that have taken place in the structure of the sign result in changes in the sphere of text and discourse. In turn, these mean that research in semiotics, stylistics, poetology, rhetoric and aesthetics (with mutual awareness of how they interact, exert an influence and interlock) cannot be credible without taking account of and updating semiotics research.

The article puts forward the thesis that the development in the forms of sign-organisation of the message, new ways of using textualis, the significant contribution of representational layer in shaping textual structure and the communicative situation all lead to the crystallisation of semiopoetics. Examples of its categories and research problems are kinetic figures (adjection, reduction, permutation, transformation, atomisation); functional homonyms; new ways of versification and narration. Discovering the sphere of semiopoetics allows one not only to reflect on newly established models of semiotics, or update poetics, but also to take a new look at texts produced using past technologies and notice previously overlooked aspects.

KEYWORDS: semiotics, semiopoetics, kinetic figures, digital text (cybertext), digital poetics

\section{Komunikacyjna i medialna służebność znaku. Problem tożsamości tekstu cyfrowego}

Podjęcie systematycznych badań semiotycznych w odniesieniu do przekazów cyfrowych wydaje się konieczne zwłaszcza wobec nieustalonego dotąd ich statusu. I nie może być inaczej, skoro badania te maja charakter szczątkowy i okazjonalny; nie ma właściwie obszerniejszych, całościowych prac, których celem byłby opis i systematyzacja zagadnienia ${ }^{1}$. A najistotniejsze zmiany w sposobie istnienia przekazu na skutek rozwoju technologii cyfrowych dokonały się w dwóch sferach: komunikacji (sposobach posługiwania się tekstem) oraz tekstury (warstwy przedstawień tekstu), której

${ }^{1}$ Choć zagadnienie to podejmowane jest w pracach wielu badaczy, na przykład: Stephena W. Smoliara, Tiny Schneider, Jaya Davida Boltera, Jörgena Schäfera Mariusza Pisarskiego, Urszuli Pawlickiej, Agnieszki Smagi, Marka Kaźmierczaka, czy piszącej te słowa. Zob. artykuły w rozdziale: W świecie znaków digitalnych, [w:] Przekaz digitalny. $Z$ zagadnień semiotyki, semantyki i komunikacji cyfrowej, red. E. Szczęsna, Kraków 2015, s. 15-111. 
podstawowa jednostka jest znak. Rozwijanie badań semiotycznych uważam za konieczne nie tyle $\mathrm{z}$ uwagi na samą zmianę $\mathrm{w}$ sferze semiotyki cyfrowego utworu literackiego, co przede wszystkim z uwagi na konsekwencje tej zmiany dla dalszego rozwoju literatury oraz jej opisu.

Znaki uwarunkowane są komunikacyjnie i medialnie. Powołuje się je do życia jako nośniki znaczeń (tworzone są niejako na zamówienie społeczne, na potrzeby międzyludzkiej komunikacji). Zmieniające się formy tej komunikacji i technologie medialne kształtują ich strukturę. Służebność znaku widoczna jest w tym, iż, obcując z tekstem, odbiorca nie myśli o znakach, które umożliwiają jego istnienie, ale skupia się na znaczeniach. Tekst istnieje w świadomości odbiorczej jako nośnik sensów, doświadczeń estetycznych, emocjonalnych, działań perswazyjnych. Tekstami są byty uznakowione (na przykład miasto jako tekst) oraz intencjonalne konstrukty semiotyczne (fotografia, powieść), którym przypisujemy znaczenie. Bez aktywności znaczeniotwórczej człowieka (zarówno w akcie nadawczym, jak i odbiorczym) nie może być mowy o tekście. Wydrukowana książka, rękopis, zapis nutowy, malowidło, rzeźba, film itp. - bez działania sensotwórczego (interpretacyjnego, ustanawiania sensów) nie jest tekstem ani nawet konstruktem semiotycznym, ale potencja tekstowa, przedmiotem tekstowym zdolnym do uruchomienia działań tekstotwórczych. Dopiero w akcie odbioru, za sprawą aktywności odbiorcy, przedmiot ten może stać się impulsem powodującym uruchomienie działań sensotwórczych (dialogu odbiorca-tekst ${ }^{2}$ ) przekształcających przedmiot tekstowy w zdarzenie tekstowe. Także dopiero wówczas staje się konstruktem semiotycznym. Tym, co przekształca przedmiot tekstowy w zdarzenie tekstowe i semiotyczne, jest aktywność znaczeniotwórcza człowieka. Forma tej aktywności warunkuje tożsamość zdarzenia tekstowego.

W kulturze cyfrowej aktywność komunikacyjna użytkownika ulega reinterpretacji. Charakterystyczne dla dotychczasowej kultury wyznaczanie formy aktywności odbiorczej przez gatunek i materię przekazu (na przykład inne dla literatury, inne dla gry planszowej) zostaje wyparte przez możliwość operowania różnymi, uzupełniającymi się wzajemnie i oddziałującymi na siebie formami komunikacji. Dobrego przykładu dostarcza literatura

${ }^{2}$ Takie myślenie zakłada obecność przedmiotu tekstowego. Ciekawym do zbadania przypadkiem jest rozmowa o przedmiocie tekstowym bez jego obecności. Jest to przypadek wypowiadania się o utworze literackim, malarskim, filmowym bez jego bezpośredniej obecności - sytuacja częsta w krytyce artystycznej, praktyce szkolnej czy akademickiej, jednak nieomawiana w literaturze przedmiotu. Mamy wówczas do czynienia z wtórną interpretacja interpretacją odnoszącą się do pamięci przedmiotu tekstowego i pamięci znaczeń ustanawianych w przeszłości w procesie jego odbioru. Jeszcze innym zagadnieniem jest wypowiadanie się o przedmiocie tekstowym bez jego znajomości, na podstawie tego, co zasłyszane. 
potencjalna (grywalna), łącząca aktywność czytelnika z aktywnością widza i gracza. To z kolei skutkuje zmianą w sferze tożsamości tekstu, który w relacji z odbiorca jest nie tylko miejscem kreowania znaczeń, ale także dziania się tekstury, angażowania cielesności użytkownika w jej ustanawianie. Maria Angel i Anna Gibbs stawiają wręcz tezę, iż pisanie w sztuce cyfrowej uzewnętrznia się bardziej za pośrednictwem gestu, ruchu ciała niż wypowiedzi językowej ${ }^{3}$, z kolei Noah Wardrip-Fruin nadaje cielesności wagę jednego z podstawowych czynników kontekstowych współtworzących utwory digitalne, obok na przykład kontekstu społecznego czy kontekstu przestrzeni" ${ }^{4}$.

Ciało odbiorcy w przestrzeni cyfrowej może być poddawane semiotyzacji - stawać się znakiem tekstowym, współtworzyć tekst. Tak jest na przykład w przypadku instalacji (Camille Utterback, Romy Achituv - Text Rain ${ }^{5}$, Camille Utterback - Still Standing ${ }^{6}$, Noah Wardrip-Fruin i in. - Screen ${ }^{7}$, gdzie ciało odbiorcy - gesty, ruchy - wchodzą w interakcję ze znakami tekstowymi, mają wpływ na sposób istnienia tekstu, którego częścią same się stają. Tak też jest w przypadku przekazów czyniących odbiorcę uczestnikiem wirtualnego świata - utworów, w których ma on swoją reprezentację semiotyczną - staje się na przykład postacią tekstowa (awatarem). Semiotyzacja użytkownika, uczynienie go elementem świata przedstawionego zdolnym do działania w przestrzeni tekstury (jak to jest chociażby w przypadku gier wideo czy cyfrowych form tekstowych - także literackich - wykorzystujących w swojej strukturze growość) jest własnością sztuki digitalnej.

Wydaje się, że w odniesieniu do odbioru tekstu sztuki, kiedy to dochodzi do czytania konstruktu semiotycznego, czyli przypisywania mu znaczeń, nie ma sensu rozważać zagadnienia identyczności tych znaczeń ani z intencją twórcy ${ }^{8}$, ani ze znaczeniami, które ustanawiane są przez innych odbiorców, gdyż wątpliwa jest jej sprawdzalność. Można natomiast mówić o zbieżnościach w sferze cech decydujących o tożsamości tekstu. W kulturze analo-

${ }^{3}$ M. Angel, A. Gibbs, Memory and motion. The body in electronic writing, [w:] Beyond the Screen. Transformations of Literary Structures, Interfaces and Genres, eds. J. Schäfer, P. Gendolla, Bielefeld 2010, s. 131.

${ }^{4}$ N. Wardrip-Fruin, Five elements of digital literature, [w:] Reading Moving Letters. Digital Literature in Research and Teaching, eds. R. Simanowski, J. Schäfer, P. Gendolla, Bielefeld 2010, s. 44.

${ }^{5}<$ https://www.youtube.com/watch?v=f_u3sSffS78> [dostęp: 8.09.2016].

${ }^{6}<\mathrm{http}$ ://collection.eliterature.org/2/works/nadeau_stillstanding.html> [dostęp: 8.09.2016].

${ }^{7}<$ http://collection.eliterature.org/2/works/wardrip-fruin_screen.html> [dostęp: 8.09.2016].

${ }^{8} \mathrm{Tu}$ pojawia się pytanie o to, czym jest intencja twórcza, jeśli nie została ona zwerbalizowana przez autora na przykład w formie komentarza do tekstu lub wyartykułowana wprost w tekście (jak to bywa w literaturze edukacyjnej, moralizatorskiej, czy szerzej tendencyjnej) oraz o to, jaka jest relacja między nią a odbiorczą interpretacją. 
gowej do takich cech zaliczyć można semiotyczną stałość przedmiotu tekstowego. Niezmienność reprezentacji semiotycznej ${ }^{9}$ stanowi tu mocną podstawę do porozumienia się w sprawie tekstu - ustalenia na przykład, o którym tekście jest mowa, dyskutowania o przesłaniach tekstu czy jego wartości estetycznej - nawet bez obecności przedmiotu tekstowego. Jest niezbędnym warunkiem nawiązania dialogu okołotekstowego. Jednocześnie konieczne różnice cech drugorzędnych konstruowanego znaczenia tekstu artystycznego służą kształtowaniu dialogu interpretacyjnego, lokują go w przestrzeni dyskursywnej, co jest warunkiem życia tekstu.

Osadzenie znaku w materii - rzeźby w kamieniu czy drewnie, obrazu w płótnie, desce, czy tekturze a także farbie, słowa literackiego w materii papieru i druku $-\mathrm{z}$ jednej strony dawało tekstowi bezpieczeństwo utrwalenia zapisu, stabilności i trwałości tekstury - potencjalnego impulsu sensotwórczego, z drugiej jednak unieruchamiało znak. Stabilizacja, trwałość zapisu, niezmienność warstwy przedstawień czyniły teksturę czymś pewnym. Już na początku lat siedemdziesiątych Roland Barthes pisał w odniesieniu do tekstu literackiego o funkcji zabezpieczającej - „stabilności, trwałości zapisu” zapobiegającego „ułomności i nieprecyzyjności pamięci”, zwracając jednocześnie uwagę na „prawomocność litery jako niepodważalnego, jak to się sądzi, nieusuwalnego śladu sensu, który autor dzieła świadomie w nim zawarł" ${ }^{10}$. Materia stawiała opór zmienności znaku i warstwy przedstawień; tekstura zostawała w niej w pewnym sensie uwięziona i uwarunkowana jej ontycznością.

W kulturze cyfrowej znak i tekstura nie są powiązane z materia. Każdy znak, każda warstwa przedstawień, niezależnie od przynależności dyskursywnej, a więc niezależnie od tego, czy reprezentują dyskurs sztuki, nauki, ekonomii, polityki, dziennikarstwa, religii, mają ten sam status bytowy (materialny), podlegają tym samym zasadom dyskursu informatycznego, mają tę samą budowę. $Z$ jednej strony pozbawienie ich materii oznacza utratę trwałości, stabilności zapisu - stąd troska o nieustanne tworzenie kopii, ochronę danych, zapis etapów zmian. Z drugiej jednak strony niematerialność i programowalność tekstury pozwalaja na nieograniczona inwencję twórczą. Każdy znak może być bowiem nieskończenie wiele razy przekształcany, każdy też, poza byciem nośnikiem znaczeń tekstowych, może pełnić funkcję narzędzia tekstowego - służyć przeprowadzaniu dzia-

\footnotetext{
${ }^{9}$ Przy czym chodzi tu o stałość cech semiotycznych pierwszorzędnych - tych, które decydują o znaczeniu podstawowym. Zmiana kroju czcionki w zapisie tekstu literackiego, zmiana oryginalnego malowidła na reprodukcję fotograficzną mogą wpływać na drugorzędne czy nawet trzeciorzędne cechy znaczeniowe, nie będą modelować cech pierwszorzędnych.

${ }^{10}$ R. Barthes, Teoria tekstu, przeł. A. Milecki, [w:] Wspótczesna teoria badań literackich za granica. Antologia, oprac. H. Markiewicz, t. 4, cz. 2, Kraków 1996, s. 190.
} 
łań na tekście a wreszcie odsyłać do innego znaku. Według Jaya Davida Boltera w akcie odnoszenia do innego znaku, nieustannego przechodzenia od jednego znaku do drugiego, zostaje ucieleśniony proces nieskończonej semiozy (o której pisał Umberto Eco) ${ }^{11}$.

Istotne przemodelowania $\mathrm{w}$ sposobie istnienia znaku w środowisku cyfrowym - w szczególności brak osadzenia w konkretnej materii, możliwość jego przekształcania sprawiaja, że nie można dłużej mówić ani o przedmiocie tekstowym, ani o niezmienności semiotycznej tekstu. Każdy element tekstury może być zaprojektowany jako zmieniający się lub możliwy do zmiany przez użytkownika - do przekształcenia czy usunięcia. Znika zatem to, co znajdowało się u podstaw identyfikowania tożsamości tekstu. Niematerialność znaku cyfrowego oraz możliwość programowania go w zmieniającej się postaci sprawiaja, że do cech wyznaczających tożsamość tekstu cyfrowego dołaczyć należy możliwą wielowariantywność warstwy przedstawień, jej otwartość na zmiany. Podstawę do identyfikacji utworu stanowi jego adres internetowy podany wraz z datą dostępu, która odsyła do tekstu w postaci, jaka miał w tym czasie.

Zmiany w sferze semiotycznej organizacji utworu oraz w sferze relacji komunikacyjnych oznaczaja inny sposób budowania świata przedstawionego, zmiany w strukturze tekstu, formach gatunkowych - krótko mówiąc, $\mathrm{w}$ sferze poetyki tekstu artystycznego. W przypadku utworu literackiego nową poetykę tekstu wyznacza przede wszystkim semantycznie wyzyskana semiotyka jego językowej organizacji, która neutralne dotychczas medium znaczeń czyni ważnym składnikiem świata przedstawionego współkreującym znaczenia tekstowe. Ta nowa, semiotycznie uwarunkowana struktura tekstu pozwala mówić o kształtowanej przez tekst cyfrowy semiotycznie uwarunkowanej poetyki.

Elementami semiotycznymi drugorzędnymi, współkreującymi znaczenia literackie w przestrzeni cyfrowej, mogą być przedstawienia stricte ikoniczne, czyli tworzone przez cyfrowe znaki plastyczne (nie zaś języka werbalnego) ruchome obrazy i dźwięki. Wskazana tu wielość form znakowych każe postawić pytanie o literackość - czy nie ulega ona w przypadku tekstów cyfrowych zatarciu lub w wielu przypadkach wręcz zniesieniu? Czy w ogóle w przypadku złożonych semiotycznie utworów cyfrowych można mówić o utworach literackich (często w literaturze przedmiotu spotkać można kategorię obiektu)?

Wydaje się, że skoro o istocie literatury decyduje bycie sztuką słowa, literaturą będzie każdy utwór, w którym dominuje funkcja estetyczna, re-

${ }^{11}$ Zob. J.D. Bolter, Writing Space. Computers, Hypertext, and the Remediation of Print, New York 2011, s. 176. 
alizowana semiotyczno-semantycznym ukształtowaniem warstwy werbalnej. Należy podkreślić, że cyfrowość pozwala na literackie wyzyskanie warstwy semiotycznej słowa. Z kolei inne niż werbalna semiosfery (na przykład towarzyszące elementy ikoniczne, muzyczne) mogą pełnić w takim przypadku funkcję kontekstowa - mogą modelować znaczenia, ale nie mogą przesądzać o istocie utworu, jeśli utwór ten ma być uznany za literacki. Na uznanie utworu za literacki lub nieliteracki nie ma natomiast wpływu kwestia autorstwa - w przestrzeni cyfrowej dochodzi coraz częściej do zastępowania autorstwa jednoosobowego współpracą wielu twórców. Powstają utwory wieloautorskie i współautorskie - kolaboratywne, w których współpraca przyjmuje różną formę i które wyznaczają tożsamość sztuki cyfrowej, w tym też literatury ${ }^{12}$.

Modyfikacji ulegaja zatem forma i status znaku literackiego, a w konsekwencji i tekstu literackiego. O ich specyfice decyduje możliwość bycia konstrukcją hybrydyczną - to samo przedstawienie jest umownym i ikonicznym nośnikiem znaczeń, może też być kształtującym znaczenia narzędziem działań (ukazywać, przenosić, przekształcać). Znaczenia te mogą uzupełniać się, wzmacniać, ale moga też wchodzić w relacje polemiki, konfrontacji, zaprzeczenia.

Inny w utworze cyfrowym jest też sposób posługiwania się przestrzenią tekstową. Tradycyjny tekst drukowany zajmuje płaszczyznę w taki sposób, że każdy pojedynczy element tekstury ma swoje miejsce, które zostaje mu „przydzielone raz na zawsze”. Każdy znak tekstowy (litera, wyraz, zdanie) powiązany jest na trwałe $\mathrm{z}$ daną przestrzenią. Czytanie związane jest zatem z wodzeniem wzrokiem po powierzchni tekstury - odbiorca, odczytując tekst (percypuje teksturę dostępna oglądowi w całości - na przykład wiersza czy fragmentu utworu prozatorskiego mieszczącego się na stronie), „wędruje” percepcyjnie po powierzchni płaszczyzny tekstury w określonym, ustanowionym przez zastaną konwencję piśmienniczą i respektowanym przez twórcę porządku; przekładając kartkę, zmienia jedną płaszczyznę na drugą analogiczna, rządząca się tymi samymi prawami.

W przedstawieniach cyfrowych możliwe jest wytwarzanie efektu trójwymiarowości znaku tekstowego i tekstury (uprzestrzennienia tekstu). Utwór może dziać się w sposób animacyjny - zarówno na drodze następstwa

${ }^{12} \mathrm{O}$ literaturze kolaboratywnej zob. na przykład G.P. Landow, Collaborative writing, collaborative authorship; examples of collaboration in hypertext, [w:] Hypertext 3.0. Critical Theory and New Media in an Era of Globalization, Baltimore 2006, s. 136-143; M. Pisarski, Twórczość kolaboratywna w literaturze cyfrowej i poza nia: próba uporzqdkowania, [w:] Między dyskursami, sztukami, mediami. Komparatystyka jutra, red. E. Szczęsna, P. Kubiński, M. Leszczyński, Kraków 2017, s. 109-127. 
pojawiających się elementów tekstury, jak i na drodze ich przekształceń. Uprzestrzennienie może być też uzyskiwane na drodze powiązania wypowiedzi językowej z dźwiękiem. W utworze Star Wars, One Letter at a Time Briana Kima Stefansa ${ }^{13}$ pojawiające się pojedynczo na ekranie litery wiązane są z dźwiękiem naciskanych klawiszy w maszynie do pisania. Dźwięk sprawia, że odbiorca narratywizuje przedstawienie ikoniczne - litery nie sa wyświetlanymi znakami, ale kolejnymi elementami tekstu pisanego przez kogoś na maszynie. Dźwięk i zmieniający się obraz tworzą zdarzenie - przykuwają uwagę odbiorcy do poszczególnych liter, każą mu składać je w słowa i większe fragmenty tekstu. Odbiorca zyskuje status uczestnika zdarzenia, niejako śledzi powstawanie tekstu, staje się wręcz częścią świata przedstawionego. Czas, w którym odczytuje tekst, nie jest późniejszy w stosunku do procesu twórczego, do powstania tekstu - jak ma to miejsce w przypadku tradycyjnego utworu, ale jest z nim tożsamy. To sprzyja prowadzeniu swoistej gry artystycznej zasadzającej się na niejasnym statusie odbiorcy, który oscyluje między byciem kimś na zewnątrz świata przedstawionego i świata tekstowego (na przykład czytelnikiem) a byciem kimś wewnątrz niego - tu zaś na przykład świadkiem-obserwatorem zdarzeń (na przykład świadomością nadrzędną tekstu) lub głównym aktantem (bohaterem piszącym na maszynie tekst).

Takie posługiwanie się przestrzenią tekstury sprawia, że zyskuje ona status znaku literackiego modelującego, uzupełniającego znaczenia słowne. Tak jest również w utworze I, You, We Dana Wabera i Jasona Pimble'a ${ }^{14}$, gdzie oddalające się i przybliżające wyrazy konotują ludzkie zachowania, działania, relacje międzyludzkie, jakie funkcjonują w życiu społecznym. Uprzestrzennienie wyrazów stanowić może reprezentację przestrzeni społecznej, zestawianie wyrazów w określonym porządku, przybliżanie się ich i oddalanie pełni funkcję znaczeniotwórcza, ma zdolność inicjowania w odbiorcy aktywności sensotwórczej. Słowa - poruszające się, udźwiękowione, zmieniające swój kształt, barwę - zyskują wartość przedmiotów tekstowych, a nawet, jak w analizowanych wyżej przykładach, poddane zostają antropomorfizacji czy personifikacji. Uprzestrzennienie, nadanie im trzeciego wymiaru pozwala na powiązanie z nimi wyobrażeń dotykowych.

Maurice Merleau-Ponty, rozważając w Fenomenologii percepcji zagadnienie percepcji elementu odbieranego zmysłowo oraz jego znaczenia ujmowanego w słowie, zauważa, że

${ }^{13}<$ http://collection.eliterature.org/1/works/stefans_star_wars_one_letter_at_a_time. html> [dostęp: 8.09.2016].

$14<\mathrm{http}$ ///collection.eliterature.org/1/works/waber_pimble_i_you_we.html> [dostęp: 8.09.2016]. 
[...] zanim pojawi się słowo, znak zmysłowy i jego znaczenie nie dadzą się oddzielić nawet idealnie. Przedmiot jest organiczna całościa kolorów, zapachów, dźwięków, odczuć dotykowych, które wzajemnie się symbolizują i modyfikują [... $]^{15}$.

Z kolei w esejach o mowie stwierdza:

[...] tak jak fakt fizyczny nowej kreski nie jest konstrukcja, podobnie w sztuce słowa, fizyczne istnienie dźwięków, zarys liter na papierze czy też fizyczna obecność tych oto gotowych zdań nie wystarczy, by powstało znaczenie. [...] Gdy czytam książkę, czuję, że wszystkie słowa się zmieniły, a nie potrafię powiedzieć, na czym polega ta zmiana. Nowość użycia języka jest określona przez pewne stałe odchylenie, z którego nie umiemy od razu zdać sobie sprawy, a więc sens książki jest językowy ${ }^{16}$.

Zarówno w jednym, jak i drugim wypadku mowa jest o znaczeniu pierwotnym, percepcyjnym lub słownikowym, niebędącym jednak znaczeniem ostatecznym, które nadawane jest przez postrzegający, ukształtowany językowo, aktywny intelektualnie podmiot.

Odnosząc myśl filozofa percepcji do literackich utworów cyfrowych, można stwierdzić, że ich znaczenie byłoby znaczeniem odnoszącym się do wyrazów-przedmiotów, wyrazów-znaków zmysłowych, które wiążą znaczenia percepcyjne i słownikowe, ale których sens ostateczny się w nich nie wyczerpuje. Sens ten pojawia się jako wartość naddana, dla której impulsem jest tekst artystyczny. Kreowany jest w akcie odbioru/użytkowania/stanowienia tekstu, w procesie twórczej reinterpretacji nie tylko pierwotnych znaczeń percepcyjnych i słownikowych, ale tė̇ w wyniku konfrontacji znaczeń wtórnych odnoszacych się do słowa-przedmiotu; słowa-znaku umownego, słowa-narzędzia tekstowego.

\section{Semantyzycja warstwy przedstawień słowa. Semiopoetyka}

Jak już zostało powiedziane, u podstaw modyfikacji tekstury hipertekstu artystycznego znajduje się zmiana w sposobie istnienia i budowie znaku cyfrowego, który nie jest jakaśs odrębna jednostką znakowa, ale reprezentacją znaku realizowana w tekście mediów cyfrowych ${ }^{17}$. Brak powiązania znaku z konkretną materia, która stawiałaby opór jego dowolnym modyfikacjom, sprawia, że może być on swobodnie przekształcany - wręcz jego cechą ontyczną jest modyfikowalność, bycie znakiem w ruchu. Ta jego cecha pozwala na to, by na poziomie tekstu możliwe było realizowanie za-

${ }^{15}$ M. Merleau-Ponty, Fenomenologia percepcji, przeł. M. Kowalska, J. Migasiński, Warszawa 2001, s. 58.

${ }_{16}$ Tenże, Proza świata. Eseje o mowie, przeł. S. Cichowicz, Warszawa 1976, s. 63.

${ }^{17}$ Strukturę znaku cyfrowego i jego ontyczność charakteryzuję w pracy: U podstaw tekstu $i$ dyskursu. Znak digitalny - specyfika i struktura, „Teksty Drugie” 2014, nr 3. 
sad konwergencji, mieszania i przetwarzania cech gatunkowych, swobodnego łączenia elementów reprezentujących różne dyskursy i media - krótko mówiąc, realizowanie opisywanej wielokrotnie w drugiej połowie ubiegłego stulecia zasady demokratyzacji kultury ${ }^{18}$. W przypadku literatury cyfrowej na przykład możliwe jest wprawienie w ruch tekstury, przekształcanie jej na oczach użytkownika. Każdy element warstwy przedstawień może zmieniać swój kształt, kolor, wielkość, może znikać, wędrować w dowolne miejsce, pojawiać się na nowo. Według George'a P. Landowa ruch wprowadza do literatury cyfrowej efekt dramaturgiczny ${ }^{19}$. W efekcie warstwa przedstawień jest tak samo ważna semantycznie jak warstwa świata przedstawionego kreowana semantyką tekstu alfabetycznego. Współtworzy ten świat i sama się nim staje. Ruchoma tekstura wytwarza znaczenia, które mogą wchodzić $\mathrm{w}$ relacje z semantyką świata przedstawionego - kreowanego przez odbiorcę w procesie czytania. Przemianie zatem ulega ontyczność impulsu tekstotwórczego, który w literaturze cyfrowej generowany jest gdzieś na przecięciu - w efekcie przenikania się i interakcji

- znaczeń ustanawianych w procesie odbioru znaków językowych (tekstury werbalnej - literowej) jako znaków umownych, transparentnych (jak w tradycyjnej powieści książkowej - ustanawianie świata przedstawionego);

- semantyki tekstury tworzonej przez ruchome znaki językowe (literowe) jako znaki ikoniczne;

- semantyki tekstury współtworzonej przez ruchome znaki językowe (literowe) jako narzędzia działań na teksturze.

Należy podkreślić, iż semantyka cyfrowego tekstu artystycznego nie jest sumą wymienionych semantyk, ale kształtuje się w ich interakcji. W efekcie zatarciu ulega ustanowiona w dotychczasowych mediach: drukowanych, piśmiennych, ikonicznych, dźwiękowych granica między znakami ikonicznymi, pisma alfabetycznego, dźwiękowymi. W przestrzeni cyfrowej istotne sa nie tyle pismo, ikona, dźwięk jako formy osobne (całościowe), co cechy: językowość realizowana w formie piśmiennej (cechy zapisu alfabetycznego) lub oralnej (wtórna oralność zapośredniczona medialnie), ikoniczność (plama barwna, linia, kształt), dźwiękowość (tu też muzyczność) jednostek znaczących. Dominacja w odczuciu odbiorczym, w procesie interpretacji, określonych cech jako definiujących tożsamość utworu wyznacza jego charakter: jako literackiego, plastycznego czy muzycznego, przy czym w przestrzeni sztuki cyfrowej cecha dominująca może być modelowana przez inne cechy - recesywne. Cyfrowy znak artystyczny charakteryzuje się wiązaniem wzajemnie oddziałujących na siebie

${ }^{18}$ Zob. na przykład C. Geertz, O gatunkach zmaconych (Nowe konfiguracje myśli społecznej), przeł. Z. Łapiński, [w:] Postmodernizm. Antologia przektadów, red. R. Nycz, Kraków 1997.

${ }^{19}$ G.P. Landow, dz. cyt., s. 91. 
cech - w przypadku literatury językowość modelowana jest ruchomą ikonicznością i dźwiękowościa, które uczestniczą w kształtowaniu znaczeń denotacyjnych i konotacyjnych.

I tak na przykład w miniaturze Arms cyklu Strings Dana Wabera ${ }^{20}$ linia układa się w napis - na oczach odbiorcy tworzone są słowa Twoje ramiona oraz mnie, zaś dwa pierwsze słowa z trzecim zostają powiązane tą samą linia, która układa się w znak okręgu. To semantyka słów nasuwa skojarzenie z aktem obejmowania. Opatrzenie takim znaczeniem rysującego się między wyrazami okręgu nadaje całości sens; odbiorca w poszukiwaniu znaczenia całości wiąże wizerunek okręgu z czasownikiem „obejmować” (,otaczać”). A zatem semantyka słów staje się istotnym kontekstem interpretacyjnym dla znaku ikonicznego współtworzącego utwór. Gdyby rysowanemu okręgowi towarzyszyły inne słowa, jego odczytanie byłoby inne (na przykład napis o bieganiu mógłby podpowiadać bieganie w koło, zaś napis o myśleniu, wspominaniu - uporczywie powracającą myśl czy wspomnienie). Znaczenie całości kształtuje się w interakcji semantyki słów i ikony. Całość jest utworem transsemiotycznym, który przywołuje ponadto tradycję innych gatunków tekstowych - w tym przypadku tradycję rebusu. Sferę konotacyjną utworu literackiego tworzy zarówno semantyka warstwy językowej, jak i semantyka warstwy ikonicznej. W przypadku wielu utworów literatury cyfrowej jest to także warstwa dźwięku - pojawiające się litery wiązane są z dźwiękiem na przykład naciskanych klawiszy klawiatury komputera (w Klikam Giełżyńskieje1 z cyklu [C()N Du It J), czy odgłosami szycia maszynowego lub krojenia nożycami materiału (w Fitting the Pattern Christine Wilks ${ }^{22}$ ). Elementy niewerbalne - ruchome ikony, dźwięki - uczestniczą w kreowaniu znaczeń dosłownych i metaforycznych; literackie jednostki znaczące zyskują transsemiotyczną strukturę.

Zmiany w sferze semiotyczno-semantycznego istnienia tekstury literackiej umożliwiają wielofunkcyjność i wielodyskursywność warstwy przedstawień. Możliwe staje się ustanawianie intertekstualności na poziomie semiotyczno-semantycznym tekstu. Oznacza to, że nawiazania do innych tekstów pojawiają się już w warstwie przedstawień. I tak na przykład instalacja Text Rain ${ }^{23}$ nawiąuje do utworu Il pleut Apollinaire'a z tomu Kaligramy właśnie na poziomie semantyki sposobu ukazywania się utworu. W instalacji opadające na ekranie słowa przywołują na myśl obecne w ka-

\footnotetext{
${ }^{20}<\mathrm{http}$ ://collection.eliterature.org/1/works/waber_strings.html> [dostęp: 8.09.2016].

${ }^{21}<$ https://vimeo.com/15657793> [dostęp: 8.09.2016].

$22<$ http://collection.eliterature.org/2/works/wilks_fittingthepattern.html> [dostęp: 8.09.2016].

${ }^{23}$ Tamże.
} 
ligramie Apollinaire'a rysowanie deszczu na papierze słowami „il pleut”. Podobnie w utworze [Ars poetica] Zenona Fajfera ${ }^{24}$ polemika z rozumieniem sztuki poetyckiej odbywa się na poziomie warstwy przedstawień. W znakowej organizacji utworu innym niż tradycyjny sposobie istnienia utworu literackiego ujęte zostaje poszukiwanie odpowiedzi na pytanie, czym w dobie kultury cyfrowej jest sztuka poetycka. Fajfer podejmuje temat znany, wielokrotnie podejmowany $\mathrm{w}$ dziejach literatury zarówno $\mathrm{w}$ dyskursie teoretycznym, jak i literackim, zawsze jednak realizowany w semantyce tekstu alfabetycznego. W [Ars poetica] tradycja ta jest ważnym kontekstem interpretacyjnym dla pokazania istotnego przesunięcia $\mathrm{w}$ sposobie realizacji idei sztuki poetyckiej.

W sztuce cyfrowej rośnie rola kontekstu semiotyczno-semantycznego innych tekstów, dyskursów, mediów. Kontekst staje się integralnym składnikiem tekstu, semantyka semiotycznej organizacji innego tekstu, jego poetyka, zamiar artystyczny zostają niejako wmontowane w tekst na prawach elementu współtworzącego znaczenia. To pozwala na kształtowanie interdyskursywności na poziomie semiotycznym. Dobrym przykładem jest cykl Strings ${ }^{25}$, w którym na poziomie ruchomej warstwy przedstawień nawiązuje się do dyscypliny przeciagania liny, dyskursu retoryki, erystyki czy rebusu. Możliwe są też odwołania do innych mediów i sztuk kreowane na poziomie tekstury - nawiązania do muzyki, filmu, sztuk plastycznych, fotografii.

Ciekawym zagadnieniem wymagającym zbadania są też relacje znaczeniowe, w jakie w cyfrowym utworze literackim może wchodzić semantyka warstwy przedstawień z semantyką tekstu alfabetycznego, tworząc intersemiotyczną intratekstualnośćc ${ }^{26}$. Komentarz, polemika, dopowiedzenie, powtórzenie, wzajemna reinterpretacja znaczeń to typy relacji, które odnaleźć można w Czarnych jagodach Susan Gibb ${ }^{27}$, Matrioszce Marty Dzido ${ }^{28}$ czy $\left[C() N\right.$ Du It] Giełżyńskiej ${ }^{29}$.

Modyfikacje znaku literackiego oraz semiotyki tekstu skutkują zatem zmianami w sferze jego poetyki. Najdobitniejszym przejawem tej zależności jest wspomniane tworzenie znaczeń w tekście słownym $\mathrm{w}$ interakcji warstwy werbalnej jako systemu znaków umownych oraz jednocześnie tej

${ }^{24}<\mathrm{http}: / /$ www.techsty.art.pl/magazyn3/fajfer/Ars_poetica_polish.html> [dostęp: 8.09.2016].

${ }^{25}$ Tamże.

${ }^{26} \mathrm{O}$ intratekstualności jako kategorii nazywającej linkowe odesłania w obrębie tego samego tekstu (co charakterystyczne jest na przykład dla hipertekstu literackiego) pisze Mariusz Pisarski. Zob. tegoż: Xanadu. Hipertekstowe przemiany prozy, Kraków 2013, s. 45.

${ }^{27}$ Utwór w przekładzie M. Pisarskiego; <http://ha.art.pl/hiperteksty/czarne_jagody/ czarne_jagody.html> [dostęp: 8.09.2016].

${ }^{28}<\mathrm{http}: / /$ www.ha.art.pl/matrioszka/start.html> [dostęp: 8.09.2016].

${ }^{29}$ Tamże. 
samej warstwy werbalnej jako systemu ruchomych i/lub udźwiękowionych znaków graficznych.

A oto przykład (fragmenty utworu booms Piotra Puldziana Płucienniczaka $\left.^{30}\right)$.

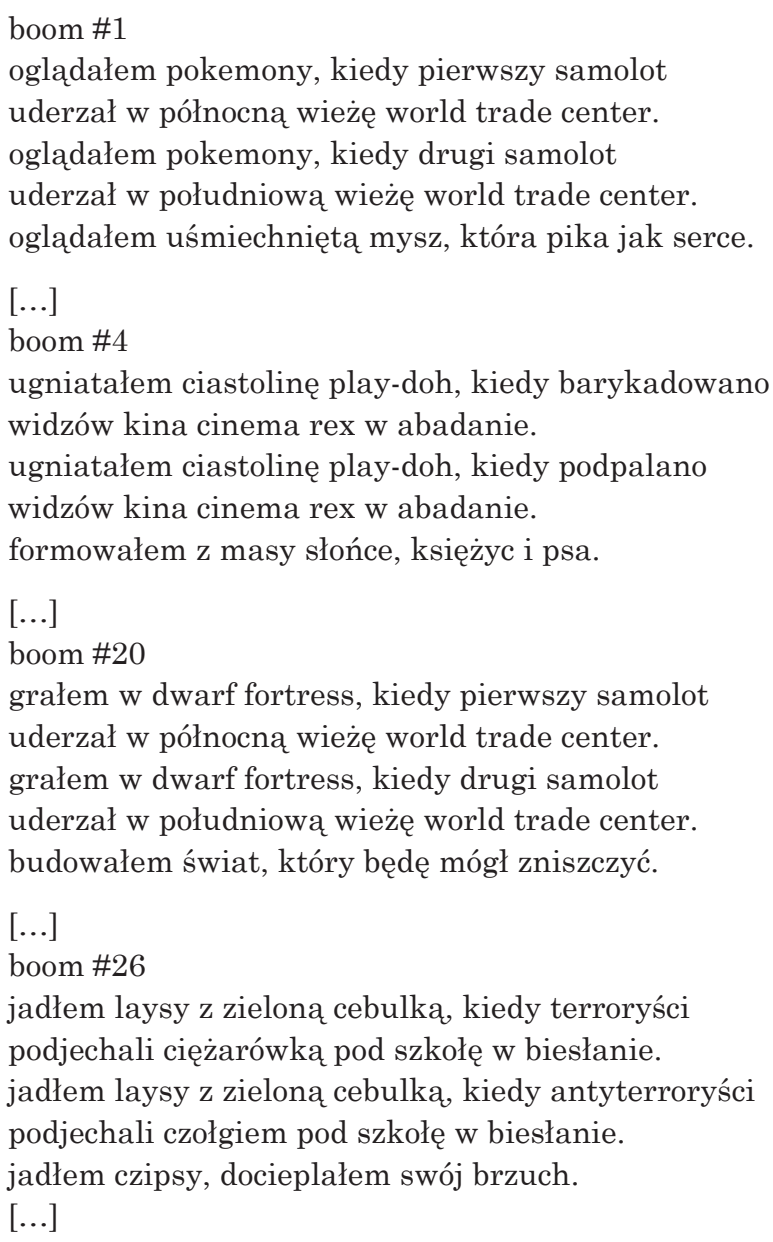

Utwór (czy może cykl) „booms” stworzony na podstawie wierszy Macieja Taranka to otwarty cykl następujących po sobie pięciowersowych fragmentów opatrzonych kolejnymi tytułami „boom\#1”, „boom\#2”, „boom\#3” itd. Każdy pojawiający się fragment, generowany cyfrowo, po upływie krótkiego czasu zastępowany jest kolejnym, mającym tę samą organizację składniowa, wersyfikacyjna, a także podobnym pod względem sensu.

W kolejnych fragmentach podmiot-bohater informuje o zamachach terrorystycznych, które miały miejsce w rzeczywistości. Dziejące się gdzie

${ }^{30}<$ http://techsty.art.pl/m10/Booms/index.html> [dostęp: 8.09.2016]. 
indziej, budzące przerażenie zdarzenia - akty terroru zostaja zestawione z mało istotnymi czynnościami i drobnymi przyjemnościami „ja” mówiącego: jedzeniem chipsów, oglądaniem filmu w telewizji, graniem w gry wideo itp. Błahe, nieistotne działania bohatera, w które wpisane sa akty zbiorowej przemocy, utrzymanie obu typów informacji w tym samym beznamiętnym tonie, brak śladów jakiegokolwiek poruszenia emocjonalnego bohatera można interpretować jako oznakę obojętności na powtarzające się akty terroru, niemocy jednostki wobec nich i nieuchronnego, powtarzanego nieustannie dziania się katastrofy. Mamy zatem do czynienia z tematem znanym, wielokrotnie pojawiającym się w sztuce drugiej połowy XX wieku (by przywołać tu choćby Piosenkę o końcu świata Czesława Miłosza czy Pan Cogito czyta gazetę Zbigniewa Herberta). Poprzestanie na semantyce przekazu słownego ukazywałoby utwór jako nie dość, że niezbyt oryginalny pod względem podejmowanego tematu, to również słaby pod względem formy (oto w kolejnych fragmentach powracają te same informacyjne frazy, które łączone są w różnych konfiguracjach).

Istotą utworu jest kreowanie znaczeń w interakcji warstwy semantycznej słowa i sposobu ukazywania się tekstu - paralelnych struktur składniowych oraz ruchu, który sprawia, że jedne informacje zastępowane są innymi - tylko pozornie odmiennymi, w istocie zaś potwierdzającymi regułę ponawianej nieustannie destrukcji. Oto numerowane kolejno części pojawiają się jedna po drugiej z tą sama częstotliwościa - jeden atak terrorystyczny zostaje zastapiony kolejnym i kolejnym. Mimo iż każda cząstka opatrzona zostaje tytułem, cykl znaczy jako niekończąca się całość; wartość semantyczną ma rytmiczne, powtarzające się w nieskończoność pojawianie się słów o kolejnych zdarzeniach tragicznych - zastosowanie paralelnych konstrukcji językowych, analogii prezentowanych, niszczycielskich zdarzeń, pojawianie się i znikanie następujących po sobie fragmentów, wreszcie sam akt generowania cyfrowego struktury oddają nieuchronność zniszczenia tego, co dotychczasowe, ale także bezrefleksyjność czynu fanatycznego. Utwór nie ma końca. Fragmenty pojawiają się w nieskończoność, tak samo, jak ciagle następują w różnych miejscach na świecie akty przemocy. Co więcej, te same zdarzenia powracaja, a towarzyszyć im moga te same lub zmieniające się czynności podmiotu (na przykład boom\#1 i boom \#20). Powtarzanie tych samych lub analogicznych zdarzeń przy zmieniających się działaniach podmiotu - tak samo mało istotnych - może służyć deprecjacji ważności konkretnego zdarzenia - bardziej niż o konkretną sytuację chodzi o nieuchronna powtarzalność aktów terroru, o sytuację bez wyjścia i brak reakcji na nią. Rytmicznie ponawiany w nieskończoność ruch znikania jednych treści i pojawiania się na ich miejsce kolejnych - podobnych, a nawet tożsamych współtworzy znaczenie estetyczne. 
Znaczący udział semiotyki w kształtowaniu struktury tekstu, formy literackiej i znaczeń sprawia, że w odniesieniu do hipertekstów literackich bardziej niż o poetyce zasadne jest mówienie o semiopoetyce, u której podstaw leży znak literacki jako ruchomy, zdolny do przekształceń znak arbitralno-ikoniczno-dźwiękowy. Kategoria semiopoetyki w odniesieniu do literatury cyfrowej akcentuje istotne przewartościowanie w sferze reguł organizacji wypowiedzi literackiej jako tworu językowego o dominującej funkcji estetycznej. Podkreśla mianowicie przewartościowanie w sferze ukształtowania językowego literatury, w którym literacko wyzyskiwany jest nośnik znaku literackiego - forma języka akustyczna i graficzna (zapis alfabetyczny). Semantyka cyfrowej wypowiedzi literackiej jest kształtowana przez semantykę słowa jako jednocześnie znaku arbitralnego, dźwiękowego i ruchomego znaku ikonicznego a także modelowana przez semantykę elementów akustycznych (tu też muzycznych) oraz ruchomych znaków plastycznych (plamy barwnej, kreski) towarzyszących wypowiedzi językowej. Ważnym czynnikiem kształtowania znaczeń tekstowych jest interfejs. Znaki cyfrowe nie tylko są nośnikami znaczeń denotowanych i konotowanych, ale także sa znakami działania na innych znakach i tekście. Zdolność przenoszenia czytelnika w różne fragmenty tekstu, przetwarzania jednych znaków przez inne - używania ich w funkcji narzędzia pracy na tekście są stałymi elementami cyfrowej semiopoetyki modyfikującymi strukturę utworu i dyskurs literacki.

Znaczna część zagadnień inicjujących rozwój dziedziny, którą określam tu jako semiopoetykę, istniała oczywiście również w literaturze wcześniej by wspomnieć tu chociażby literaturę oralna, ale także poezję wizualna - od starożytności (na przykład twórczość Teokryta), po czasy nowożytne (na przykład twórczość George'a Herberta, Marinettiego, Apollinaire’a, u nas zaś Tytusa Czyżewskiego, Stefana Themersona czy Stanisława Dróżdża) ${ }^{31}$. Zjawiska te były jednak dla literatury bardziej marginalne niż reprezentatywne. Jako takie nie wypracowały repertuaru zmieniających się w czasie form, które inicjowałyby potrzebę typologii, czy wypracowania osobnego repertuaru narzędzi badawczych. Nie rościły sobie prawa do wyjścia poza tradycyjna poetykę, w ramach której znajdowały i/lub wytwarzały narzędzia opisu.

W przypadku środowiska cyfrowego zmiana sposobu istnienia tekstu literackiego jest stała, gdyż powodowana zmianą ontyczności znaku. Transsemiotyczne tworzenie znaczeń literackich skutkuje istotnymi przemodelowaniami w strukturze tekstu, literackiej wersyfikacji, stylistyce, genologii,

${ }^{31}$ Zob. S. Wysłouch, Literatura i semiotyka, Warszawa 2001, <http://www.dwutygodnik. com/artykul/1450-liberatura-slowo-ikona-przestrzen.html> [dostęp: 15.09.2016] oraz umieszczona pod tekstem literatura przedmiotu. 
które uzasadniają badania nad semiopoetyka. I tak na przykład narzędziami semiopoetyki będą figury ruchu - jak chociażby: adiekcja (dodawanie elementów w teksturze), redukcja (odejmowanie, zanikanie tych elementów), permutacja (ich przestawianie, przemieszczanie), atomizacja (ich rozpad) oraz transformacja (zmiana kształtu, wielkości, barwy elementu tekstury). Mówienie w tym przypadku o figurach w pełni uzasadnia fakt, iż zabiegi te uczestniczą w tworzeniu znaczeń tekstowych, realizowaniu pomysłu artystycznego. Od tropów różnią się jedynie tym, że są sensotwórczymi działaniami na tkance znakowej tekstu, a nie bezpośrednio na znaczeniach. Wytworem semiopoetyki będą też homonimy funkcyjne polegające na jednoczesnym przypisaniu określonemu słowu funkcji bycia nośnikiem znaczeń, uczestniczenia w ich kreowaniu oraz funkcji mediacyjnej lub operacyjnej - przenoszenia użytkownika do innej partii tekstu, spajania różnych fragmentów, czy wreszcie przekształcania warstwy przedstawień tekstu. W ramach semiopoetyki mieszczą się także przemodelowania w sposobie istnienia struktur tekstowych od zawsze definiujących literaturę - takich jak narracja czy metafora, które kreowane są w interakcji semantyki ruchu, ikony, dźwięku oraz języka; ale także w interakcji form dyskursywnych, medialnych oraz działań użytkownika.

Dobrego przykładu dostarcza wiersz Roberta Kendalla Faith ${ }^{32}$ mówiący między innymi o sile wiary, której argumenty logiczne nie są w stanie pokonać. Niezmienność, stałość wiary, jej moc wobec tego, co racjonalne, logiczne obrazują spadające kilkakrotnie na słowo „wiara” liczne słowa „logika”, które odbijają się od niego i znikaja, podczas gdy słowo „wiara”, stanowiące jednocześnie tytuł utworu, trwa niezmiennie; dominując umiejscowieniem, funkcją i rozmiarami nad zmieniającą się całością tekstu. Dopiero pojawiająca się pod koniec myśl - być może samobójcza, a może nazywająca upadek, postawę poddania się, rezygnacji - myśl o skoku, przekroczeniu krawędzi, za która jest przepaść bez dna, myśl, która zdominuje wszystkie inne myśli, sprawia, że wiara upada. Dominacja myśli o skoku, przedstawiona w semantyce słowa jako jedyna prawdziwa myśl, w warstwie tekstury zyskuje postać słowa „skok”, które stopniowo powiększa się, a jednocześnie wyodrębnia z pozostałej tekstury. Ruch rosnącego słowa „skok” w stronę odbiorcy sprawia, że cała powierzchnia ekranu zostaje przez nie zajęta, a pozostały tekst zostaje przysłonięty i przesunięty na dalszy plan - jak gdyby to, co konstytuowało dotąd myśli, światopogląd, osobowość podmiotu przestawało być ważne, a może wręcz legło w gruzach. Ilustracją tego może być finalne „odrywanie się" słów tekstu od swojego miejsca na ekranie i ich spadanie na dolną krawędź ekranu jedne na drugie tak, że tracą swoją semantyczną

${ }^{32}<$ http://collection.eliterature.org/1/works/kendall_faith.html> [dostęp: 15.09.2016]. 
moc, przestają być znaczącym tekstem, a stają się kupką niepotrzebnych śmieci. Jako ostatnie upada tytułowe słowo „wiara”.

Semantyka tekstu alfabetycznego i semantyka warstwy przedstawień (tekstury) wchodzą we wzajemne relacje interpretacyjne. Sa to relacje metaforyczne, gdyż sensy denotowane i konotowane przez jedną $\mathrm{z}$ warstw przenikają w sferę znaczeń drugiej warstwy, modelując jej znaczenia; są to również relacje analogii (czy powtórzenia), gdyż intuicje znaczeniowe obecne w semantyce warstwy werbalnej znajduja potwierdzenie w semantyce tekstury i odwrotnie; sa to wreszcie relacje narracyjne, gdyż ruch pojawiających się różnobarwnych liter, rozsuwających się, powiększających, opadających i obracających wyrazów sprawia, że odbiorca nadaje im wartość przedmiotów, bytów ożywionych i cech mentalnych człowieka, wiąże w relacje przyczynowe, aktywizuje figurę implikacji, która leży u podstaw narracji - krótko mówiąc, nadaje utworowi lirycznemu wartość opowieści (narratywizuje go).

Interesujący jest też sposób istnienia wersyfikacji. Utwór nie jest dany jako całość, a znaczenia nie są ustanawiane w procesie liniowego czytania słowo po słowie - jak funkcjonuje to w tradycyjnej liryce. Utwór niejako staje się na oczach odbiorcy, jego dalszy przebieg musi być kilkakrotnie inicjowany przez użytkownika, który, klikając na strzałki u dołu ekranu (z towarzyszącymi im słowami nazywającymi ciag dalszy, wynikanie), uruchamia dalsze dzianie się tekstu, ustanawianie tekstury. Dodawane litery, tworzace na bazie jednego słowa inne, przekształcające wyrazy w inne wyrazy; dodawane słowa, rozsuwające się słowa w celu umieszczenia między nimi innego słowa, które modyfikuje znaczenie całości; nadto operowanie różnymi barwami (kolejnym etapom zmian przypisane są inne barwy) - wszystko to służy ustanawianiu zmieniającej się ciagle formy wiersza i modyfikacji znaczeń. Tekst budowany jest na oczach odbiorcy, na prawach palimpsestu semiotycznego oraz semantycznego. Znaczy jako kinetyczna, ikoniczna, dźwiękowa całość - znaczy w każdej kolejnej odsłonie - dodawanych elementów, ale także w interakcji kolejnych odsłon. Wersyfikacja, której konstytutywną cechą są ruchomość, barwa, dźwięk, przekształcenia formy; nadto transsemiotyczne, kinetyczne metafory i narracja, intersemiotyczne powtórzenia - to narzędzia semiopoetyki.

$$
* * *
$$

Reasumując, zaprezentowane zmiany w sposobie istnienia znaku literackiego w przestrzeni utworów cyfrowych; wskazane konsekwencje tekstowe i dyskursywne owych zmian - tu zwłaszcza zmian w sferze komunikacji literackiej, sposobu kształtowania utworu literackiego (jego poetyki), 
generowanych znaczeń artystycznych, dowodzą konieczności rozwoju badań semiotycznych w ramach badań literaturoznawczych i szerzej - tekstologicznych. Konieczne jest też powiązanie tych badań z poetyka jako ta, która poddawana jest reinterpretacji w efekcie znaczącego udziału tekstury w kształtowaniu struktury tekstu artystycznego. Ważne jest, by badania nad tekstem cyfrowym (i sztuką cyfrowa) wykorzystywały na prawach narzędzia dorobek poetyki, teorii komunikacji, badania z zakresu filozofii i psychologii percepcji oraz semiotyki - w tym ostatnim wypadku w myśl de Saussure'a, Peirce'a, Greimasa, Łotmana, Eco, Barthesa, Hjelmsleva, Uspienskiego, czy - na gruncie polskim - Seweryny Wysłouch.

\section{BIBLIOGRAFIA}

Angel M., Gibbs A., Memory and motion. The body in electronic writing, [w:] Beyond the Screen. Transformations of Literary Structures, Interfaces and Genres, eds. J. Schäfer, P. Gendolla, Bielefeld 2010, s. 123-136.

Barthes R., Teoria tekstu, przeł. A. Milecki, [w:] Wspótczesna teoria badań literackich za granica. Antologia, oprac. H. Markiewicz, t. 4, cz. 2, Kraków 1996, s. 189-209.

Bolter J.D., Writing Space. Computers, Hypertext, and the Remediation of Print, New York 2011.

Geertz C., O gatunkach zmaconych (Nowe konfiguracje myśli społecznej), przeł. Z. Łapiński, [w:] Postmodernizm. Antologia przekładów, red. R. Nycz, Kraków 1997, s. 214-236.

Landow G.P., Collaborative writing, collaborative authorship; examples of collaboration in hypertext, [w:] Hypertext 3.0. Critical Theory and New Media in an Era of Globalization, Baltimore 2006, s. 136-143.

Merleau-Ponty M., Fenomenologia percepcji, przeł. M. Kowalska, J. Migasiński, Warszawa 2001.

Merleau-Ponty M., Proza świata. Eseje o mowie, przeł. S. Cichowicz, Warszawa 1976.

Pisarski M., Twórczość kolaboratywna $w$ literaturze cyfrowej i poza nia: próba uporzadkowania, [w:] Między dyskursami, sztukami, mediami. Komparatystyka jutra, red.

E. Szczęsna, P. Kubiński, M. Leszczyński, Kraków 2017, s. 109-127.

Pisarski M., Xanadu. Hipertekstowe przemiany prozy, Kraków 2013.

Szczęsna E., U podstaw tekstu i dyskursu. Znak digitalny - specyfika i struktura, „Teksty Drugie" 2014, nr 3, s. 67-86.

W świecie znaków digitalnych, [w:] Przekaz digitalny. Z zagadnień semiotyki, semantyki i komunikacji cyfrowej, red. E. Szczęsna, Kraków 2015, s. 15-112.

Wardrip-Fruin N., Five elements of digital literature, [w:] Reading Moving Letters. Digital Literature in Research and Teaching, eds. R. Simanowski, J. Schäfer, P. Gendolla, Bielefeld 2010, s. 29-58.

Wysłouch S., Literatura i semiotyka, Warszawa 2001.

$<$ http://collection.eliterature.org/1/works/kendall_faith.html> [dostęp: 15.09.2016].

$<$ http://collection.eliterature.org/1/works/stefans_star_wars_one_letter_at_a_time. html> [dostęp: 8.09.2016]. 
<http://collection.eliterature.org/1/works/waber_strings.html> [dostęp: 8.09.2016].

<http://collection.eliterature.org/1/works/waber_pimble_i_you_we.html> [dostęp: 8.09.2016].

$<$ http://collection.eliterature.org/2/works/nadeau_stillstanding.html> [dostęp: 8.09.2016]. $<$ http://collection.eliterature.org/2/works/wardrip-fruin_screen.html> [dostęp: 8.09.2016]. <http://collection.eliterature.org/2/works/wilks_fittingthepattern.html> [dostęp: 8.09.2016].

<http://ha.art.pl/hiperteksty/czarne_jagody/czarne_jagody.html> [dostęp: 8.09.2016].

<http://techsty.art.pl/m10/Booms/index.html> [dostęp: 8.09.2016].

$<$ http://www.dwutygodnik.com/artykul/1450-liberatura-slowo-ikona-przestrzen.html> [dostęp: 15.09.2016].

<http://www.ha.art.pl/matrioszka/start.html> [dostęp: 8.09.2016].

$<$ http://www.techsty.art.pl/magazyn3/fajfer/Ars_poetica_polish.html> [dostęp: 8.09.2016].

$<$ https://vimeo.com/15657793> [dostęp: 8.09.2016].

<https://www.youtube.com/watch?v=f_u3sSffS78> [dostęp: 8.09.2016]. 